\title{
Hemosuccus pancreaticus
}

\section{Report of a case associated with cyst forming undifferentiated carcinoma}

of the pancreas and review of the literature -

\section{ORIGINAL ARTICLE Annals of Cancer Research and Therapy}

\author{
Toshiro Fukushima - Kenji Tanehiro *1), Ryuji Asai ${ }^{* 2)}$ \\ Tatsuo Uchida · Hiroshi Kojima · Hiroya Murakami *3), \\ Kazuhiko Ohashi · Nobumasa Toda*4), Mitsunori Yasue · Junichi Sakamoto*3)
}

\begin{abstract}
A rare case of gastrointestinal hemorrhage due to rupture of a pseudoaneurysm into the pancreatic duct in a patient with undifferentiated carcinoma of the pancreas is described. The diagnosis was made by recognizing bleeding from the papilla of Vater at duodenoscopy and was corroborated by the findings of selective angiography and CT scanning.

Review of the previously reported cases was also performed, and the pathogenesis, diagnosis, and treatment of hemosuccus pancreaticus are discussed in relation to the present case.

This unusual cause of gastrointestinal bleeding should be considered when the common diseases have been excluded.
\end{abstract}

Ann Cancer Res Ther 4 (1) : 33 37, 1995/Received 1 Mar 1995, Accepted 17 Apr 1995

Key words : hemosuccus pancreaticus,

carcinoma of the pancreas, pseudoaneurysm, duodenoscopy

Hemorrhage through the pancreatic duct, a rare cause of gastrointestinal bleeding, usually results from rupture of an aneurysm or a pseudoaneurysm of the splenic / hepatic artery or their branches into the pancreatic duct. This condition was first reported in 1931 by Lower \& Farrell ${ }^{\text {!) }}$. In 1970, Sandblom ${ }^{21}$ termed this condition "hemosuccus pancreaticus", while Longmire \& Rose ${ }^{3 \prime}$ suggested the name "hemoductal pancreatitis" in 1973 and Favriel" named it "Wirsungorrhagia" in 1979.

Inflammation of the pancreas is usually described as the underlying cause, but others have also been reported including ruptured pseudoaneurysm ${ }^{5)}$ and ulceration of the duplicated stomach and duodenum with bleeding through the papilla of Vater $^{3}$.

The following case report describes a patient with a cyst forming undifferentiated carcinoma of the pancreas who developed major upper gastrointestinal bleeding when a pseudoaneurysm in the cyst wall developed a communication with the pancreatic duct.

\section{Case report}

A 70-year-old man was admitted to Aichi Prefectural Hospital in May 1993 with melena and dyspnea on exertion. He had undergone right pneumonectomy 4 years previously

\footnotetext{
*1'Departments of Internal Medicine, ${ }^{* 21 R a d i o l o g y, ~ a n d ~}{ }^{*}$ 'Surgery, Aichi Prefectural Hospital

*+1Department of Endoscopy, Aichi Cancer Center

Correspondence to : Junichi Sakamoto, Department of Surgery \& Laboratory of Clinical Oncology, Aichi Prefectural Hospital, 18 Kuriyado. Kakemachi, Okazaki 444, Japan
}

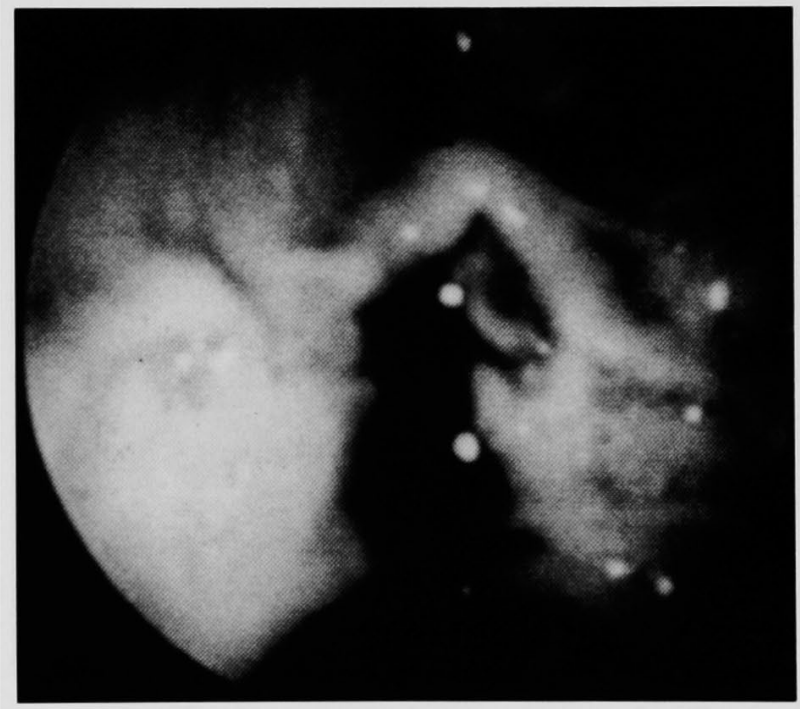

Fig. 1 Duodenoscopy detected the continuous oozing of blood from the papilla of Vater

for stage I large cell lung cancer. Physical examination on admission revealed marked conjunctival pallor. No abdominal pain or tenderness was noticed. Laboratory studies revealed that his hemoglobin value was $4.6 \mathrm{~g} / \mathrm{dL}$ on admission. Evaluation at that time included endoscopic examination of the upper and lower gastrointestinal tract, barium meal follow through, and intestinal scintigraphy, the results of which were all negative. Because of his continuing melena and severe anemia, he received a transfusion of 12 units $(1,560 \mathrm{ml})$ of packed red blood cells. 


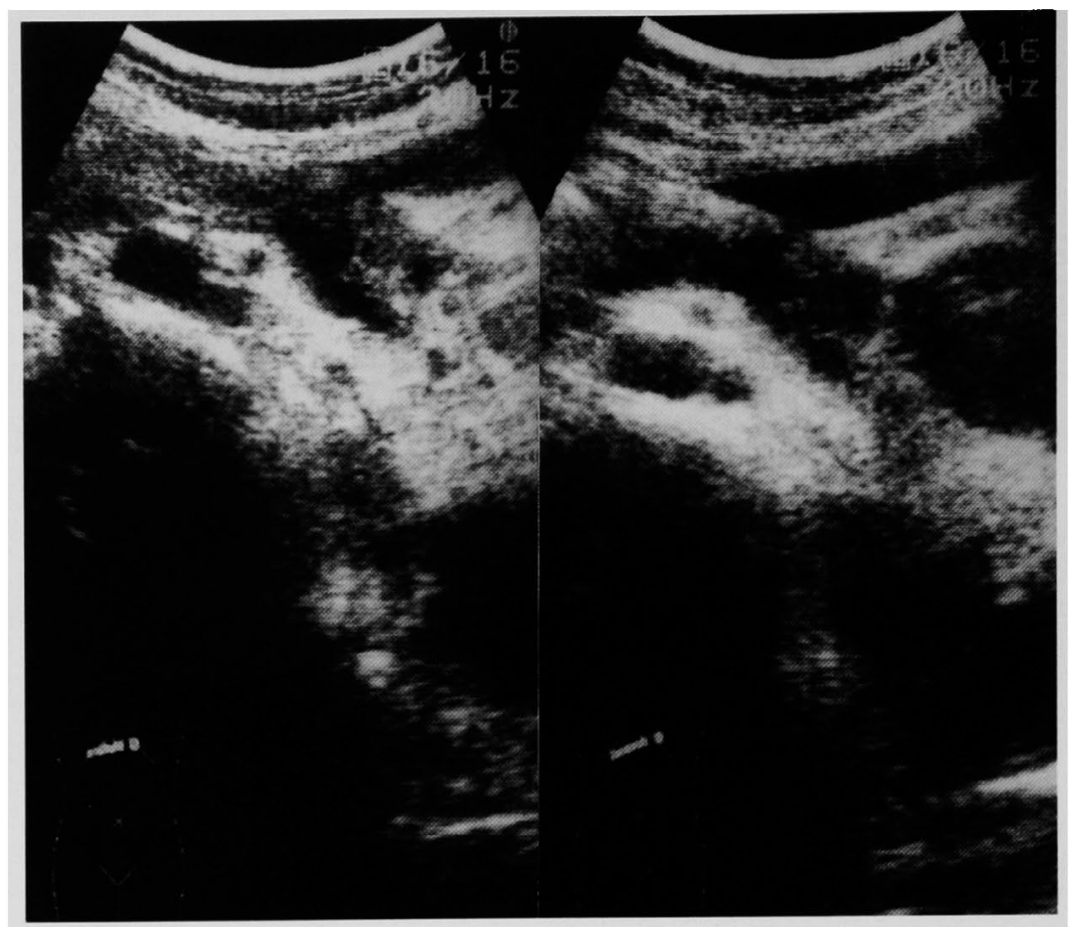

Fig. 2 Ultrasonography revealed a $3.5 \mathrm{~cm}$ hypoechoic mass in the body of the pancreas

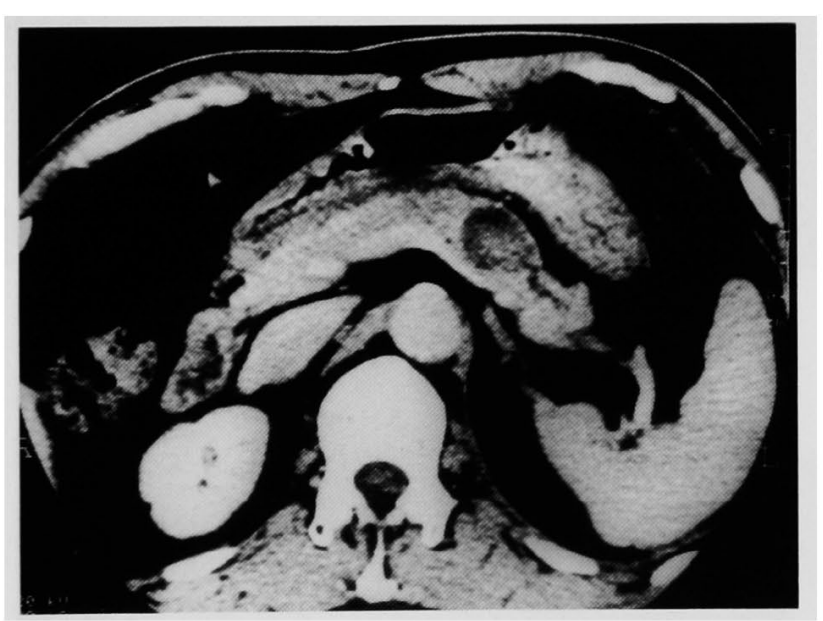

Fig. 3 Axial computerized tomography showed a pancreatic mass with a relatively high density area inside

After transfusion, the source of the bleeding was again investigated by duodenoscopy and bright red blood was noticed oozing from the papilla of Vater (Fig. 1). Endoscopic retrograde cholangiopancreatography (ERCP) demonstrated obstruction of the main pancreatic duct at the body of the pancreas. Cytologic examination of the ERCP specimen was negative for cancer. Ultrasonography (US) revealed a hypoechoic, well-demarcated mass about $3.5 \mathrm{~cm}$ in diameter in the body of the pancreas and also showed moderate dilatation of the pancreatic duct distal to the mass (Fig. 2).

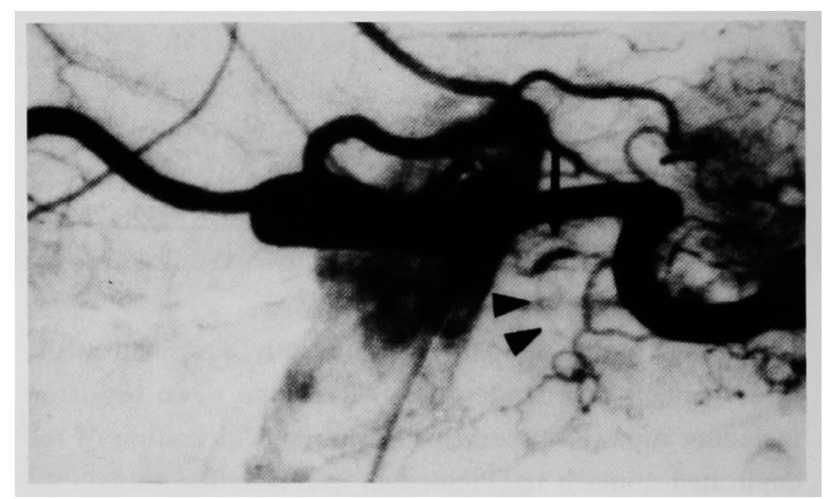

Fig. 4 Selective celiac artery angiography showed a pseudoaneurysm of the dorsal pancreatic artery Neither collateral vessels nor a tumor stain was noticed around the mass in the body of the pancreas

Simultaneous axial computed tomography (CT) also demonstrated a round mass in the body of the pancreas without contrast enhancement (Fig. 3). Selective celiac angiography showed tortuous vessels surrounding the mass and a large pseudoaneurysm arising from the dorsal pancreatic artery (Fig. 4).

A preoperative diagnosis of pancreatic pseudocyst or cystcarcinoma as the cause of hemosuccus pancreaticus was made, and surgery was performed on the 49 th hospital day. Upon exploration, a cystic mass in the body of the pancreas 


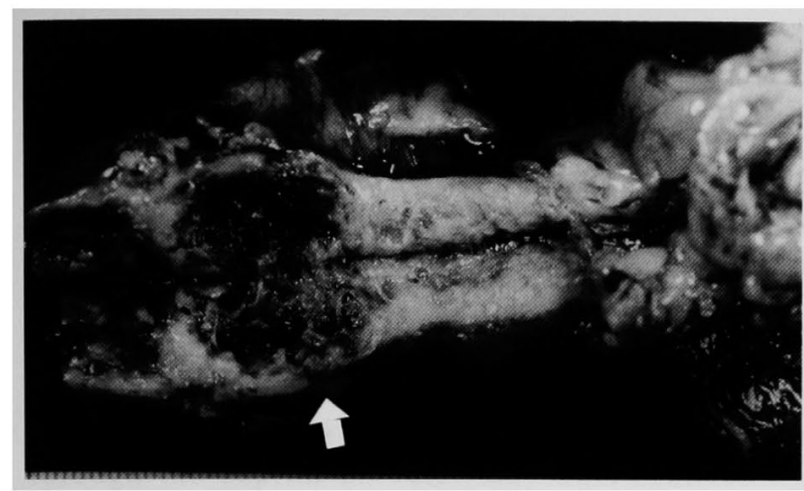

Fig. 5 The resected specimen with the spleen at the lower right

The arrow indicates the cystic tumor in the body of the pancreas.

was confirmed, and the body and tail of the pancreas were removed together with the spleen. The postoperative course was uneventful and the patient was discharged after 4 weeks. Seven months later. he is progressing well and has healthy CT scans.

\section{Pathologic findings}

The resected specimen consisted of a portion of the pancreas measuring $9.0 \times 4.5 \times 3.0 \mathrm{~cm}$ (Fig. 5). The cut surface showed black thrombus and clots in the cyst and in the pancreatic duct. In the tail of the pancreas distal to the cystic mass, the parenchymal tissue revealed fibrosis and inflammatory changes and the main pancreatic duct was mildly dilated. The cyst itself was a round mass measuring $3.5 \mathrm{~cm}$ in diameter and its wall was irregular with multiple small nodules of various sizes. Microscopic examination revealed cells with severe atypia in and around the cyst wall as well as organized thrombus and necrotic tissue. The cyst wall consisted of large nucleated atypical cells without gland formation and the pathological diagnosis was undifferentiated carcinoma of unknown origin (Fig. 6).

\section{Discussion}

Although hemosuccus pancreaticus has been considered a rare cause of bleeding from the duct of Wirsung, the improving sophistication and accuracy of the diagnostic modalities available may well increase the chance of identifying this condition.

A total of 33 cases were found by our review of the literature $^{(\hat{n}-20)}$ (Table 1). The age varied between 15 and 86 years, and the male to female ratio was $2: 1$ (22 males and 11 females). There was a previous history of gastrointestinal bleeding before the diagnosis was confirmed in $79 \%$ of the patients. Signs of pancreatitis were also noted in 17 cases $^{1-20)}$. In some patients, pancreatitis was considered to have caused the aneurysm or pseudoaneurysm, and in other cases it may

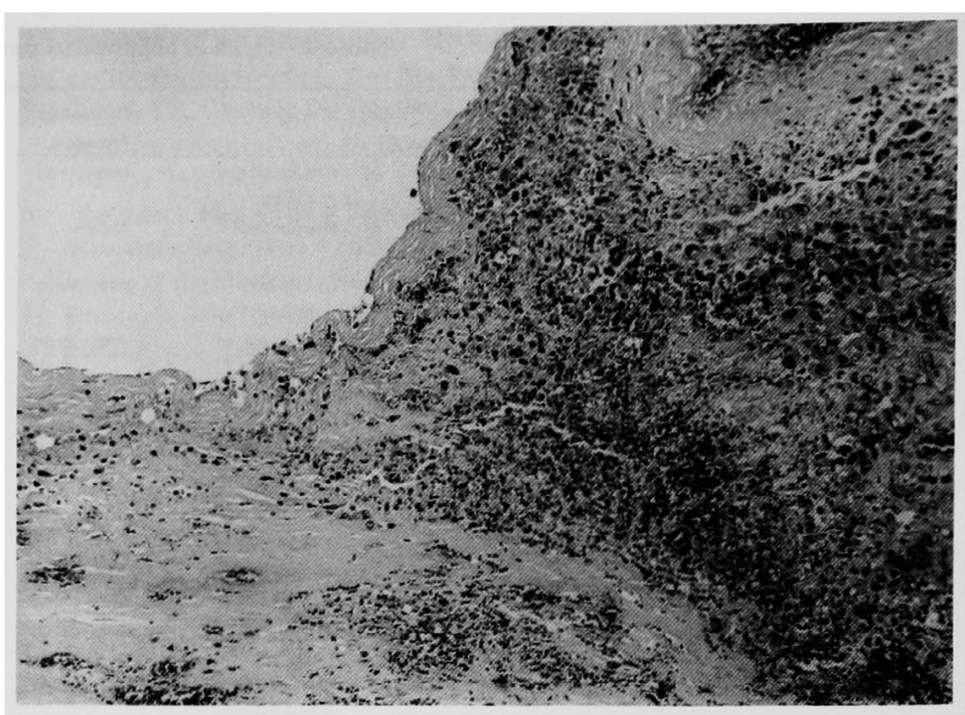

Fig. 6 Histologic section of the cyst wall Thrombus was recognized in the cyst and in the main pancreatic duct. The wall of the cyst consisted of undifferentiated carcinoma cells of unknown origin.

have been a secondary reaction to bleeding into the pancreatic duct. The source of bleeding was either an aneurysm or a pseudoaneurysm (with or without a pancreatic pseudocyst) that formed a fistula communication with the pancreatic duct.

\section{Etiology and pathogenesis}

In considering the pathogenesis of this condition, differentiation between aneurysm and pseudoaneurysm as the origin of the bleeding is important. In only two cases has the cause of hemosuccus pancreaticus been documented as a true aneurysm of the splenic artery, which was atherosclerotic in nature ${ }^{2.13)}$. In most of the other cases, the bleeding was from a pseudoaneurysm associated with pancreatitis or some other cause. These pseudoaneurysms probably arise as a result of enzymatic destruction of the arterial wall by a mechanism similar to the pancreatic necrosis that leads to hemorrhage and pseudocyst formation ${ }^{(4.15)}$. In our present case, unlike the previous ones, the pseudoaneurysm was closely related to a cystic carcinoma. Although the thrombus in the cyst strongly suggested the rupture of a vessel at that site, there is also a possibility that necrosis of a tumor involving a branch of the splenic artery was the direct cause of ductal bleeding.

Concerning the origin of the carcinoma, it could be a primary tumor or a metastasis from the previous lung cancer. A relatively high incidence of pancreatic metastasis of small cell carcinoma of the lung has been reported ${ }^{21)}$ and this taken together with the unusual pattern of growth of the cystic tumor suggests the possibility of metastasis. On the other hand, immunostaining with anti-sialyl-Lewis ${ }^{2}$ antibody (CA 19.9) demonstrated this antigen in the lung cancer but not in 
Table 1 Cases of hemosuccus pancreaticus reported in the English literature

\begin{tabular}{|c|c|c|c|c|c|c|c|c|c|}
\hline $\begin{array}{l}\text { Case } \\
\text { No. }\end{array}$ & $\begin{array}{l}\text { Age } \\
\text { (Yrs) }\end{array}$ & Sex & History * & $\begin{array}{l}\text { Diagnustic } \\
\text { Prixcedure }\end{array}$ & $\begin{array}{l}\text { Definitive } \\
\text { Operatiun* }\end{array}$ & $\begin{array}{l}\text { Involved } \\
\text { Artery+ }\end{array}$ & $\begin{array}{l}\text { Hisfological } \\
\text { Pancreatitis }\end{array}$ & Prognosix & $\begin{array}{l}\text { Author } \\
\text { (Year) }\end{array}$ \\
\hline 1. & 16 & $\mathbf{M}$ & $\begin{array}{l}\text { Abdominal pain } \\
\text { \& melend }\end{array}$ & Laparotomy & $\begin{array}{l}\text { DP+ligation } \\
\text { of antery }\end{array}$ & $\mathrm{SpA}$ & + & Survived & $\begin{array}{l}\text { Lower } \\
\text { (1931) }\end{array}$ \\
\hline 2. & 80 & $M$ & Hematemesis & Autupsy & none & SpA & + & Died & $\begin{array}{l}\text { Hentel } \\
\text { (1966) }\end{array}$ \\
\hline 3. & 59 & $\mathbf{M}$ & $\begin{array}{l}\text { Gl bleeding } \\
\text { (subtural GTX) }\end{array}$ & Laparotomy & $D P+S P X$ & SpA & + & Survived & $\begin{array}{l}\text { Jones } \\
\text { (1968) }\end{array}$ \\
\hline 4. & 51 & $\mathbf{M}$ & $\begin{array}{l}\text { Gl blecding } \\
\text { (GTX) }\end{array}$ & Arteriogram & $\mathrm{DP}+\mathbf{S P X}$ & SpA & + & $?$ & $\begin{array}{l}\text { Boijsen } \\
(1969)\end{array}$ \\
\hline 5. & 51 & M & $\begin{array}{l}\text { Abutrminal pain } \\
\text { GI bleeding (GTX) }\end{array}$ & Arteriugram & $\mathrm{DP}+\mathrm{SPX}$ & SpA & + & Survived & $\begin{array}{l}\text { Sandblam } \\
\text { (1970) }\end{array}$ \\
\hline 6. & 69 & $\mathbf{M}$ & $\begin{array}{l}\text { Abduninal pain } \\
\& \text { hematemesis }\end{array}$ & Anteriogram & $\mathrm{DP}+\mathbf{S P X}$ & SpA & - & & \\
\hline 7. & 15 & $\mathbf{F}$ & $\begin{array}{l}\text { Abduminal pain } \\
\& \text { hemaremesis }\end{array}$ & Arteriuggram & PD & PDA & - & Survived & $\begin{array}{l}\text { Lougmire } \\
\text { (1973) }\end{array}$ \\
\hline 8. & 68 & M & $\begin{array}{l}\text { Abduminal pain } \\
\& \text { melena }\end{array}$ & Arteriugram & $\begin{array}{l}\text { DP+SPX+ } \\
\text { GJstsmy }\end{array}$ & SpA & - & Survived & $\begin{array}{l}\text { Soeno } \\
(1974)\end{array}$ \\
\hline 9. & 54 & $\mathbf{F}$ & Gl bleeding & Anteriogram & PD? & IPDA & $?$ & Died & $\begin{array}{l}\text { Brintnall } \\
\text { (1974) }\end{array}$ \\
\hline 10. & 46 & $M$ & $\begin{array}{l}\text { Abdominal pain } \\
\& \text { hematemesis }\end{array}$ & Anteriugrain & $\mathrm{DP}+\mathrm{SPX}$ & $\mathbf{S p A}$ & $?$ & Survived & $\begin{array}{l}\operatorname{Lam} \\
\text { (1975) }\end{array}$ \\
\hline 11. & so & $\mathbf{F}$ & $\begin{array}{l}\text { Melena } \\
\text { (colectumy) }\end{array}$ & Aneriogram & $\mathrm{DP}+\mathrm{SPX}$ & SpA & + & $?$ & $\begin{array}{l}\text { Kinehler } \\
\text { (1976) }\end{array}$ \\
\hline 12. & 62 & $\mathbf{F}$ & $\begin{array}{l}\text { Melena } \\
\text { (colectomy) }\end{array}$ & Arteriogram & $\mathrm{DP}+\mathrm{SPX}$ & SpA & + & $?$ & $\begin{array}{l}\text { Bowers } \\
\text { (1976) }\end{array}$ \\
\hline 13. & 57 & $\mathbf{M}$ & $\begin{array}{l}\text { Recurrent } \\
\text { pancreatitis }\end{array}$ & Arteriugram & Not Stated & SpA & + & $?$ & $\begin{array}{l}\text { Walier } \\
\text { (1977) }\end{array}$ \\
\hline 14. & 62 & $\mathbf{F}$ & Gl bleeding & Arteriogram & $\begin{array}{l}\text { DP+SPX } \\
\text { ligation }\end{array}$ & SpA & + & Survived & $\begin{array}{l}\text { Bivins } \\
\text { (1978) }\end{array}$ \\
\hline 15. & 59 & M & $\begin{array}{l}\text { Abdomninal pain } \\
\text { \& hematemesis }\end{array}$ & Antriogram & $\begin{array}{l}\text { Ligation of } \\
\text { artery }\end{array}$ & SpA & + & Survived & $\begin{array}{l}\text { Starling } \\
(1979)\end{array}$ \\
\hline 16. & 73 & $M$ & Gl bleeding & Arteriogram & $\mathrm{DP}+\mathrm{SPX}$ & SpA & - & $?$ & $\begin{array}{l}\text { Favriel } \\
\text { (1979) }\end{array}$ \\
\hline 17. & 54 & $\mathbf{F}$ & Abdominal pain & Antriogram & $\mathrm{DP}+\mathrm{SPX}$ & SpA & + & $?$ & $\begin{array}{l}\text { Lung } \\
(1980)\end{array}$ \\
\hline 18. & 57 & $\mathbf{M}$ & $\begin{array}{l}\text { Melena } \\
\text { (colectomy) }\end{array}$ & Arteriogram & DP+SPX & $S_{p} \mathbf{A}$ & + & Survived & $\begin{array}{l}\text { Newstead } \\
(1980)\end{array}$ \\
\hline 19. & 65 & $\mathbf{M}$ & $\begin{array}{l}\text { Abdominal pain } \\
\text { \& hemaremesis }\end{array}$ & Arteringram & $\begin{array}{l}\text { SPX+ } \\
\text { ligatiun }\end{array}$ & SpA & $?$ & Survived & $\begin{array}{l}\text { Borjessom } \\
\text { (1981) }\end{array}$ \\
\hline 20. & 42 & $\mathbf{F}$ & $\begin{array}{l}\text { Hemaremesis } 8 \\
\text { melena }\end{array}$ & Arreringram & $\begin{array}{l}\text { SPX+ } \\
\text { ligation }\end{array}$ & SpA & $?$ & Survived & \\
\hline 21. & 50 & M & $\begin{array}{l}\text { Abdominal pain } \\
\& \text { hematemesis }\end{array}$ & Lapartotomy & $D P+S P X$ & SpA & + & Survived & $\begin{array}{l}\text { Hall } \\
(1982)\end{array}$ \\
\hline 22. & 29 & $\mathbf{M}$ & Abduminal pain & $\begin{array}{l}\text { Laparotumy+ } \\
\text { Arteriogram }\end{array}$ & $\begin{array}{l}\text { Subiutal PX } \\
+ \text { SPX }\end{array}$ & $\mathrm{CHA}$ & + & Survived & $\begin{array}{l}\text { Cahow } \\
\text { (1983) }\end{array}$ \\
\hline 23. & 35 & $\mathbf{M}$ & Abdominal pain & Areriogram & $\mathrm{DP}+\mathrm{SPX}$ & SpA & + & $\begin{array}{c}\text { Died } \\
\text { (liver failure) }\end{array}$ & \\
\hline 24. & 47 & $\mathbf{M}$ & $\begin{array}{l}\text { Abulominal pain } \\
\text { \& melena }\end{array}$ & Arteringram & $\begin{array}{l}\text { Ligatiun of } \\
\text { artery }\end{array}$ & $\mathrm{CHA}$ & $?$ & Suvived & \\
\hline 25. & 38 & $\mathbf{M}$ & $\begin{array}{l}\text { Hematemesis \& } \\
\text { melena }\end{array}$ & $\begin{array}{l}\text { Endiscopy \& } \\
\text { Arteriogram }\end{array}$ & $D P+S P X$ & $\mathrm{SpA}$ & + & Survived & $\begin{array}{l}\text { Yukoyama } \\
\text { (1984) }\end{array}$ \\
\hline 26. & 62 & $\mathbf{F}$ & G1 bleeding & Arreringraln & $D P+S P X$ & PMA & + & $?$ & $\begin{array}{l}\text { Clay } \\
\text { (1985) }\end{array}$ \\
\hline 27. & 64 & $\mathbf{M}$ & Abdominal pain & Anteriogram & DP+SPX & SpA & $?$ & $?$ & \\
\hline 28. & 50 & $\mathbf{M}$ & Abdominal pain & Anteriogram & $D P+S P X$ & DPA & $?$ & $?$ & $\begin{array}{l}\text { Yoshikai } \\
\text { (1986) }\end{array}$ \\
\hline 29. & 51 & $\mathbf{M}$ & Melena & Laparotumy & $\begin{array}{l}\text { DP+SPX+ } \\
\text { ligation }\end{array}$ & SpA & - & Survived & $\begin{array}{l}\text { Gutman } \\
\text { (1991) }\end{array}$ \\
\hline 30. & 59 & $\mathbf{F}$ & Abduminal pain & Arteriogram & $\begin{array}{l}\text { resection } \\
\text { of uneurysm }\end{array}$ & PHA & $?$ & Sunived & $\begin{array}{l}\text { Cruy. } \\
(1992)\end{array}$ \\
\hline 31. & 86 & $F$ & $\begin{array}{l}\text { Melena } \\
\text { (colectomy) }\end{array}$ & Arteriogram & $\begin{array}{l}\text { resection } \\
\text { of aneurysm }\end{array}$ & $\mathrm{SpA}$ & $?$ & Survived & $\begin{array}{l}\text { Waugner } \\
\text { (1994) }\end{array}$ \\
\hline 32. & 54 & $F$ & Anemia & Arteriogram & PD & IPDA & $?$ & Survived & $\begin{array}{l}\text { Amaud } \\
\text { (1994) }\end{array}$ \\
\hline 33. & 70 & $\mathbf{M}$ & $\begin{array}{l}\text { Melena \& } \\
\text { dyspnes }\end{array}$ & Arteringram & $D P+S P X$ & DPA & $\begin{array}{c}- \\
\text { (carcinoma) }\end{array}$ & Survived & $\begin{array}{l}\text { present } \\
\text { calse }\end{array}$ \\
\hline
\end{tabular}

Abbreviations :

\#: GI=gastrointestinal, GTX=gastrectomy.

*: $\mathrm{DP}=$ distal pancreatectomy, $\mathrm{SPX}=$ splenectomy, $\mathrm{PD}=$ pancreaticoduodenectomy, GJstomy=gastrojejunostomy, $P X=$ pancreatectomy

$+:$ SpA=splenic artery, $\mathrm{PDA}=$ pancreaticoduodenal artery, $\mathrm{CHA}=$ common hepatic artery, PMA=pancreatico magna artery, PHA=proper hepatic artery,

IPDA=inferior pancreaticoduodenal artery 
the pancreatic tumors, suggesting that the undifferentiated cystic cancer was a primary tumor of the pancreas.

\section{Diagnosis}

The diagnosis of this condition on initial referral to hospital is very difficult to establish, mainly because the bleeding is intermittent in most cases and a definite angiographic or endoscopic diagnosis is possible only during active bleeding. Recently, duodenoscopy and ERCP have come to play an important role in marking the diagnosis. Active bleeding through the papilla of Vater may be visualized by duodenoscopy ${ }^{17)}$, and indirect evidence of bleeding may also be detected by ERCP demonstrating filling defects in the pancreatic duct after the injection of contrast medium. In our case, duodenoscopy revealed bleeding from the papilla of Vater and ERCP showed obstruction of the duct of Wirsung, suggesting the presence of blood clots. CT was also useful in defining the size and location of the mass and in displaying the dilated distal main pancreatic duct. All these modalities, however, were unable to determine whether the cystic mass was benign or malignant.

\section{Treatment}

Pancreatic resection including the pseudoaneurysm and pseudocyst is recommended by most authors as the treatment of choice ${ }^{4.8)}$. Simple bipolar ligation with excision of the aneurysm ${ }^{(3)}$, percutaneous transcatheter embolization ${ }^{22)}$, or balloon occlusion "2) have also been reported as useful temporary measures. However, with recent progress in operative techniques and supportive therapy, the definitive procedure is presently considered to be distal pancreatectomy combined with splenectomy. Our patient underwent distal pancreatectomy and neither recurrence of the tumor nor recurrent bleeding has been observed to date.

\section{References}

1) Lower WE, Farrell Jl. Aneurysm of the splenic artery: Report of case and review of the literature. Arch.Surg. 23:182-190, 1931.

2) Sandblom $P$. Gastrointestinal hemorrhage through the pancreatic duct. Ann Surg. 171:61-66, 1970.

3) Longmire WP Jr, Rose AS. Hemoductal pancreatitis. Surg Gynecol Obstet, 136:246-250, 1973.

4) Favriel J, Cerf M, Sterin P, Boutelier P, Debray C. Rupture of an aneurysm of the splenic artery into the pancreas: A rare cause of gastrointestinal bleeding. Sem Hop Paris, 55:1 125-1128, 1979.

5) Cahow CE, Gusberg RJ, Gottlieb LJ. Gastrointestinal hemorrhage from pseudoaneurysms in pancreatic pseudocysts. Am J Surg, 145:534-541, 1983.

6) Yokoyama I, Hashımi MA, Srinivas D, Shaikh KA, Levine SM, et al. Wirsungorrhagia or hemoductal pancreatitis: Report of a case and review of the literature. Am J Gastroenterol, 79:764-768, 1984.

7) Brintnall BB. Laidlaw WW, Papp JP. Hemobilia: Pancreatic pseudocyst hemorrhage demonstrated by endoscopy and arteriography. Dig Dis, 19:186-188, 1974.

8) Lam AY, Bricker RS. Pancreatic pseudocyst with hemorrhage into the gastrointestinal tract through the duct of Wirsung. Am J Surg, 129:694-695, 1975

9) Luns JA, Schow PD, Knight L. Splenic artery aneurysm-pancreatic duct fistula. Am J Surg, 139:430-431, 1980.

10) Newstead GL. Splenic artery-pancreatic duct fistula. Aust NZ J Surg, 50:190-193, 1980

11) Borjesson B, Evander A, Ihse I, Joelsson B, Lunderquist A Gastrointestinal bleeding caused by hemosuccus pancrearicus. A presentation of two cases. Acta Chir Scand, 147:299-301, 1981.

12) Bivins BA, Sachatello CR, Chuang VP, Brady P. Hemosuccus pancreaticus (hemoductal pancreatitis): Gastrointestinal hemorthage due to rupture of a splenic artery aneurysm into the pancreatic duct Arch Surg, 113:751-753. 1978.

13) Starling JR, Crummy AB. Hemosuccus pancreaticus secondary to ruptured splenic artery aneurysm. Dig Dis Sci, 24:726-729. 1979.

14) Clay RP, Farnell MB, Lancaster JR, Weiland LH, Gastout CJ. Hemosuccus pancreaticus: An unusual cause of upper gastrointestinal bleeding. Ann Surg, 202:75-79, 1985.

15) Yoshikai T, Murakami J, Nishihara H. Hemosuccus pancreaticus: CT manifestations. J Comput Assist Tomogr, 10:510-512, 1986.

16) Rivlin E, Gutman H, Deutsh AA, Reiss R. Hemosuccus pancreaticus and intraperitoneal bleeding secondary to spontaneous rupture of the splenic artery. Isr Med Sci, 27:150-152, 1991.

17) Fernandez-Cruz L, Pera M, Vilella A, Llovera JM, Navasa M, Teres J. Hemosuccus pancreaticus from a pseudoaneurysm of the liepatic artery proper in a patient with a pancreatic pseudocyst Hepato-Gastroenterol, 39:149-151, 1992.

18) Boijsen SR, Redman HC, Joseph RR. Angiographic findings in pancreatitis. Am J Roentogenol Radium Ther Nucl Med, 107:56-64, 1967.

19) Wagner WH, Cossman DV, Treiman RL, Foran RF, Levin PM, Cohen JL. Hemosuccus pancreaticus from intraductal rupture of a primary splenic artery aneurysm. J Vasc Surg, 19:158-164, 1994.

20) Arnaud JP, Bergamaschi R, Serra-Maudet V, Casa C. Pancreatoduodenectomy for hemosuccus pancreaticus in silent chronic pancreatitis. Arch Surg, 129:333-334, 1994.

21) Johnson DH, Hainworth JD, Greco A. Extrahepatic biliary obstruction caused by small-cell lung cancer. Ann Intern Med, 102:487-490, 1985

22) Knight RW. Kadir S, White RI.Jr. Embolization of bleeding transverse pancreatic artery aneurysms. Cardiovasc Intervent. Radiol, 5:37-39, 1982 